\title{
Royally represented or royally shafted? Effect of positive and negative captions and ideological beliefs on readers' evaluations of Kate Middleton and Meghan Markle
}

\author{
Anita A. Azeem ${ }^{1}$ \\ John A. Hunter \\ Ted Ruffman \\ University of Otago, New Zealand
}

To cite this article: Azeem, A., Hunter, J. A., \& Ruffman, T. (2021). Royally represented or royally shafted? Effect of positive and negative captions and ideological beliefs on readers' evaluations of Kate Middleton and Meghan Markle. World of Media. Journal of Russian Media and Journalism Studies 4: 5-32. DOI: 10.30547/worldofmedia.4.2021.1

\begin{abstract}
We conducted a randomized controlled experiment to investigate the role of descriptive captions (positively and negatively worded) and ideological beliefs (Right Wing Authoritarianism and Social Dominance Orientation) on viewers' evaluations of two popular British Royal family members namely Meghan Markle and Kate Middleton. Participants included 300 undergraduate students from Dunedin, New Zealand who were randomly assigned to one of the four conditions: (1) Pro-Kate, (2) Anti-Kate, (3) Pro-Meghan or (4) AntiMeghan captions accompanying the parallel images of these Royal members. We also included several distractor variables about other Royal family members and traditions. Outcomes were recorded as evaluations of six royal members (Charles, Diana, William, Harry, Kate, and Meghan). We found no significant effect of caption manipulation on outcome evaluations of Meghan and Kate. However, social dominance negatively correlated with Meghan and Harry whereas authoritarianism positively correlated with ratings of Charles. Our results indicate that a one-off exposure to biased media regarding celebrities may not significantly alter audience's evaluations of them, but ideological beliefs may influence this process, nonetheless.
\end{abstract}

\section{${ }^{1}$ Corresponding author}

Anita A. Azeem, Department of Psychology, University of Otago, PO Box 56,

Dunedin, New Zealand.

E-mail: anita.azeem@otago.ac.nz; aroonanita@gmail.com 


\section{Keywords}

Biased media, biased picture captions, SDO, RWA, Royal Family.

\section{Introduction}

Celebrities spend millions of dollars on marketing agencies to create a positive image in the media (Grunig 1993). Earnest followers of such sources may become psychologically involved with the celebrity as they develop a sense of intimacy with them owing to the amount of time and energy they have invested in reading or watching stories about them (Levy, 1979). Thus, media sources (like magazines, TV, newspapers and websites) act as reservoirs of beliefs and values which can shape public attitudes towards individuals, groups of people and issues (McCombs \& Shaw, 1972). With the advent of tabloids, social media and online news, celebrity and political news has become not only widespread but also a potential source of misinformation (Frampton, 2015). To be the most 'liked' and 'shared' source of information, channels try to find the most unique or sensational news regarding celebrities which may or may not be true.

\section{Royal family and the media}

Members of the British Royal family have traditionally graced the entertainment pages of news, covers of magazines and make numerous appearances on television. In fact, on 2 June, 1953, when the coronation of Queen Elizabeth II took place, many families reportedly bought their first TV sets to watch and the Daily Express carried a headline describing it as 'Queen's Day-TV's Day' (Clancy, 2019). It was a special time in history as the public could now witness a highly exclusive event. Since then, several events of the Royal family have been viewed by billions of people around the world. Nearly 2.5 billion people in 200 countries (Baker, 2014; Brown, Basil, \& Bocarnea, 2003) reportedly viewed Princess Diana's funeral in 44 different languages, making it one of the most watched events in history (Payne, 2000).

Several studies thereafter were conducted on the effects of news media reports on audience reactions (Myers, 2000; Puijk, 2009; Thomas, 2008). Months after her death, researchers started doubting if Diana's death was mourned as strongly by the audience around the globe as the media had portrayed. It was argued by researchers that the audience had learnt their reaction from the media portrayal of events (Dayan \& Katz, 1992; Linenthal, 2001) and that the media created emotions in the public (Couldry, 2003; Lukes, 1975). 
Given that a) media influences perception about celebrities, b) There is a general interest in the British Royal Family all around the globe and c) there is a recent Royal member who could be classified as an outgroup member based on her biracial descent, we examined the impact of biased media on perceptions of Meghan Markle as compared to Kate Middleton. The reason for comparing these two is obvious. Both of have a several things in common a) they are influential women b) they were not born royal and c) both frequently appear on fashion magazines covers and are evaluated by TV channels and the audience for their fashion and life choices.

\section{Representation of Kate and Meghan}

Ever since Prince Harry announced his engagement to Meghan Markle, journalists have been busy publishing various news stories regarding Meghan and her family. In 2018, Time and Daily Express mentioned that Meghan would modernize the Royal family (Attiah, 2018). Meghan is different from all the other royal members because of several reasons: she is biracial, a divorcee and an actress with strong feministic opinions (Ardifa \& Yamin, 2020). However, Meghan's racial background has been highlighted by the media more often than her previous job, her nationality or her ex marriage. It appears that her ethnicity makes it most difficult for people to accept her as a part of the Royal Family. For instance, in 2018, Glamour Magazine and the Sun published the following headlines respectively: "Meghan Markle is an American woman, a daughter to a black mother and a white father, a descendant of those enslaved and those who were always free" and "[H]er mother is black with dreadlocks, and she passes as Caucasian; she often received hurtful comments about whether Doria was her real mum." (Ardifa \& Yamin, 2020).

Recent scientific findings also indicate that Kate is generally represented in a more positive manner than Meghan by all newspapers (Eriksson, 2020; Ribot, 2019). Some specific examples targeting Meghan's racial background can be seen as published by The Guardian on 20 May, 2018, "The excitement about a black princess simply underlines how anachronistic the royal family really is." Lastly, in comparison to Kate, The Guardian on 17 December published, "The rumour itself is enough the angry black woman [Markle] making a Defenceless white woman [Middleton] cry is exactly the kind of thing the press has prepped for since Meghan entered the royal family." The distinction between the two is clear by the last headline. Clearly Meghan's biracial identity is overpowering all her achievements at least in how the UK tabloids represent her and although she and Kate are both are married to Princes, it appears that the media generally presents them quite differently. 
In fact, some media critics have noted that there is a disparity in the reporting of Meghan Markle vs. reporting of Kate Middleton even in instances when they both made the exact same choices. For instance, on 21 May, 2018, the British tabloid, Daily Mail published a picture of Kate Middleton entitled, "Pregnant Kate tenderly cradles her baby bump while wrapping up her royal duties ahead of maternity leave" (Brennan, 2018). The same source, on 28 January, 2019, published pictures of pregnant Meghan Markle with the title, "Why can't Meghan Markle keep her hands off her bump? Experts tackle the question..." Similarly, on September 14, 2017, The Express carried the headline, "Kate's morning sickness cure? Prince William gifted with an avocado for pregnant Duchess." But on January 23, 2019, the Daily Mail published, "Meghan Markle's beloved avocado linked to human rights abuse and drought, millennial shame." (Brookes, 2020). Meghan Markle has been represented in the media quite differently than Kate Middleton even when she made similar choices and decisions, and when the pictures accompanying the headlines were near identical, leading to the conclusion that Meghan Markle has frequently been demonized and presented negatively (Brookes, 2020).

Mahfouz (2018) investigated Meghan Markle's portrayal on Facebook and noted that those who posted about her can be clearly divided into two groups: pro-Meghan and anti-Meghan. The former often highlighted her independence, achievements, strength and involvement with the UN. The anti-Meghan group, on the contrary, focused on her racial descent, her profession as an actress and her previous marriage. This research indicates that indeed individuals have quite polarized opinions about her. It is then worth considering what the impact of negative media representations can be.

\section{Impact of media representation}

Two popular theories in media studies that have been extensively used to understand media representations are Agenda Setting Theory (McCombs \& Shaw, 1972) and Framing theory (Goffman, 1974). Agenda setting research focuses on which issues are emphasized in the media whereas framing theory focuses on how they are discussed (Weaver, 2007). Minority groups, particularly ethnic and gender minorities, are largely underrepresented in the media and they are frequently portrayed negatively (Ramasubramanian, at al., 2017). Currently, African Americans are the only ethnic minority that receives a proportional amount of publicity (i.e. receives as much airtime on prime television as the percentage of population) (Behm-Morawitz, \& Ortiz, 2013). However, this amount of publicity is not good news as the content is 
often laden with stereotypical representations. So regardless of how frequently an individual or group appears in the media, a greater concern is how they are represented (framed in the media) and more importantly how that impacts the media consumers' attitudes, evaluations, emotions and behaviours.

The US media has recurrently framed ethnic minority groups as "a burden on the nation's economy", "violators of American traditions", the "most important problem in the country" (Dunaway, et al., 2007; Johnson, et al., 2003) as well as a threat to us (Atwell Seate \& Mastro, 2016; Dragojevic, et al., 2016). Similarly, Hanson-Easey and Augoustinos (2010) argued that the UK media systematically represented others as a threat to the dominant community.

Anumber of researchers have evaluated media content in terms of the resulting emotional valence (positive or negative) and arousal (strength of emotion). For instance, threat, danger, war, destroy, fear and illegal are all negatively valenced words that cause high arousal in the readers and are frequently used to describe outgroup members (Barrett, 2004). African Americans have consistently been portrayed as "criminals", "lazy", "violent", and "troublemakers" (Oliver, 1994; Staples, 2011). This ethnic minority has been the most well-researched, with all studies pointing to the same conclusion, that is, they are frequently represented as inferior, less civilized, are four times more likely to appear as perpetrators of crimes than as police officers on TV and are often overrepresented in violent roles and severely underrepresented in positive roles (Dixon \& Linz, 2000; Eberhardt, 2019;). Women of colour also have a higher probability of appearing as hyper-sexual and workers who lack a work ethic (Tukachinsky, et al., 2015). In fact, Behm- Morawitz and Ortiz (2013) noted that a few character types have been developed to describe an African American woman and most TV representation is confined to these characterizations: Black Mammy (a faithful and asexual servant to white characters), Jezebel (a woman with somewhat lighter complexion who is highly sexualized and aggressively competes for White males' attention) and Sapphire (angry black female).

Suchbiasinframesimpactanaudience'sattitudesandbehaviours regardingfat prejudice (Frederick, Tomiyama, Bold, \& Saguy, 2020), mentalillness (Gwarjanski \& Parrott, 2017), ethnic minorities (Cho, Gil de Zuniga, Shah, \& McLeod, 2006) and immigrants (Jacobs \& van der Linden, 2017) in a direction predictable from the bias. For instance, Frederick, Tomiyama, Bold, and Saguy (2020) found that fat-negative frames predicted support for policies discriminating against obese people, higher anti-fat attitudes and negative judgments of fat people, whereas fat-positive frames predicted more inclusive attitudes and behaviours. Similarly, negatively worded news story regarding North African immigrants lead to an 
increase in unfavourable attitude towards that ethnic group whereas positively worded news had the opposite effect (Jacobs \& van der Linden, 2017). Thus, for this unique study, our main interest was in comparing how consumption of biased posts/news affected viewers' perceptions of these royal members? At present it is unknown although general studies in news framing suggest that audiences' attitudes and behaviours are influenced by how the media frames issues (Entman, 1993).

\section{Audiences' prior knowledge and attitude}

No discussion on media manipulation would be complete without considering individual differences within the audiences. For instance, would media manipulation work or individuals who have greater prior knowledge about the issue? What about those who already have fixed beliefs?

Some studies have suggested that well-informed recipients are less likely to relyon media alone (Huber \& Lapinski, 2006; Schemer, 2012). Likewise, somepreexisting dispositions (e.g., intolerance, high prejudice) may prevent individuals from altering their attitudes or behaviours even after exposure to positive media (e.g., Amir, 1969; Mastro \& Tukachinsky, 2011). These studies highlight the importance of prior knowledge and pre-existing beliefs. Hence, when studying bias in news stories, it is also important to include measures of prior knowledge and ideological beliefs as well. Below, we consider two measures of biased beliefs.

Social Dominance Orientation (SDO; Sidanius \& Pratto, 1999) and RightWing Authoritarianism (RWA; Altemeyer, 1998) have emerged as two robust predictors of prejudice (Wilson \& Sibley, 2012). SDO and RWA both measure prejudice but researchers argue that they relate to different types of prejudice (Altemeyer, 1998; Duckitt, 1993; Sidanius \& Pratto, 1999). SDO measures an individual's support for group-based hierarchy (Sidanius \& Pratto, 1999). For instance, someone who score high on SDO would support existing social groupings and suggest that we should not strive for equality. RWA, on the other hand, focuses on submission to authority, conventionalism and obedience to those in power, for instance, teachers, political leaders and parents.

SDO is sustained by the need to enforce existing hierarchies whereas RWA emphasizes submission to authority and the maintenance of existing conventions and norms (Altemeyer, 1998; Duckitt, 1993; Sidanius \& Pratto, 1999). Thus, both SDO and RWA are likely to impact on attitudes towards British royal family. Those high in both would see the royal family as upholding conventions and norms, helping to enforce existing hierarchies ('blue bloods' of noble birth 
worthy of the throne versus commoners), and emphasizing submission to authority (with royals deemed to have a key role in guiding society). In this light, Kate Middleton might be seen as worthy since she is English, White, came from a wealthy family, and attended exclusive boarding schools. In contrast, although Meghan Markle also attended an exclusive preparatory school, she is American, mixed race, and did not come from a particularly wealthy family. As a result, those high in SDO and RWA might see Kate Middleton as more entitled to her role in the royal family than Meghan Markle.

\section{Current study}

In the current study, we presented photographs along with captions pertaining to British royal family members. Our use of photographs and accompanying captions (rather than lengthy articles or videos) was because the arrival of digital images was accompanied by a surge in the use of photographs in online and print sources (McNamara, 2011). Our main interest was in Kate Middleton versus Meghan Markle, although we included neutral information about other royal family members so that our research question isn't obvious to the participants. The experimental photographs pictured the two main protagonists in near equal circumstances (e.g., with Kate Middleton and Meghan Markle both fondly caressing their baby bumps).

Given that (a) media representation may alter an audience's attitudes, (b) there is a lot of interest in the British royal family even outside Britain and c) SDO and RWA are related to prejudice, we hypothesized that:

1) Participants who viewed positive captions about Kate Middleton or Meghan Markle would rate each more positively than those who viewed negative captions about each.

2) Prior knowledge or involvement with the royal family would also be an important factor in the evaluations such that participants who a lot of prior information may be biased to view Meghan Markle negatively and Kate Middleton positively (given the bias present in the popular press), and therefore may not be influenced by the positive or negative captions.

3) People higher in prejudiced attitudes (SDO and RWA) would rate Meghan Markle more harshly, and in contrast, would display positive feelings for other royal members. 


\section{Methodology \\ Participants}

University students $(N=300)$ completed a survey on Qualtrics $($ C). Of these, 151 completed it in our research lab and 149 completed it from their home due to the covid-19 crisis. We inserted 12 attention questions throughout the survey and there were no significant differences between the attention scores of those who completed the study in the lab $\left(M={ }_{I} 0.97 ; S D=1.33\right)$ and those who completed it online from home $(M=10.86$; $S D=1.33), t(296)=.748, p=.455$. Therefore, we combined the data retaining only participants that had a score of 11 or 12 on the attention questions $(\mathrm{N}=216 ; 186$ females). On average, these participants were 20 years old $(S D=3.06)$. Ninety-seven percent of the participants were currently enrolled in an undergraduate degree, with $65.7 \%$ pursuing a degree in Arts.

When asked if they would rate themselves as politically right or left, ranging from 1-9 (where 1 referred to political left and 9 referred to politically right) more respondents identified as politically left $(M=3.83$; $S D=1.74)$. When asked if they support the British monarchy (on a scale from 1-9, where a high score meant higher support), participants displayed modest support for monarchy $(M=3.85 ; S D=2.08)$. When asked how much prior information they had about the Royal family $(1=$ none at all, $2=$ A little bit, $3=$ A moderate amount, $4=$ ardent follower), most indicated that they had no to little prior information $(M=1.53$; $S D=708$ ).

\section{Procedure and Material}

Participants were recruited via the Otago University's experimental participation pool and received course credit for completing the study on Qualtrics $@$, an online survey platform. After providing informed consent and basic demographic information, participants completed the 6-item versions of the SDO and RWA scales (Appendix A).

The participants then watched a short video introducing them to the British Royal family. The video simply explained how Queen Elizabeth was related to Prince Charles, Princess Diana, Harry, Will, Kate and Meghan. After watching the introductory video, participants viewed 32 picture/caption sets: 26 of these were distractor slides and 6 were experimental slides. The distractor slides had pictures and neutral descriptions about Prince Charles, Princess Diana, Prince William and Prince Harry. These stimuli were consistent across the four experimental groups. However, the six experimental slides were inserted amongst these distractors in a random order. We used four caption conditions for 
these experimental slides (see Appendix $B$ ), with participants randomly assigned to one condition: Pro-Kate $(N=55)$, Anti-Kate $(N=56)$, Pro-Meghan $(N=51)$ and Anti-Meghan $(N=54)$. The descriptions in Appendix B appeared with a relevant image of either Kate or Meghan. Further, all six experimental slides were taken from actual British tabloid stories, including the Daily Mail, Mirror, Express and Sun, and were balanced by, for instance, turning a pro-Kate headline like, "Pregnant Kate tenderly cradles her baby bump while wrapping up her royal duties ahead of maternity leave" (Daily Mail: March 22, 2018) and replacing 'Kate' with 'Meghan' for the pro-Meghan group. Likewise, we used actual anti-Meghan captions like, “Why can't Meghan Markle keep her hands off her bump?" and replaced 'Meghan Markle' with 'Kate Middleton' for the anti-Kate experimental group.

At the end of all the slides, participants were asked to rate Prince Charles, Princess Diana, Prince William, Prince Harry, Meghan Markle and Kate Middleton along different dimensions (See Appendix $C$ ).

\section{Measures}

We used five measures for this study.

Royal Ratings. Attitudes towards the royal family members were measured by asking participants to rate each royal member along 20 dimensions on a nine-point Likert scale (see Appendix $C$ ). This scale was adapted from Hunter et al. (2015), who used it for assessing intergroup discrimination. In this way, 20 ratings were obtained for each royal family member in this study (Charles, Diana, Kate, William, Meghan, and Harry). Ten negative adjectives were reversescored (unhelpful, cold, selfish, unfair, dishonest, untrustworthy, inconsistent, arrogant, shy and hypocritical) and averaged with the 10 positive adjectives (cooperative, intelligent, strong, flexible, sincere, friendly, soft-spoken, nonaggressive, well-informed, reticent and confident) to compute a composite score for outcome feelings for each royal member. A higher score on this scale reflected more favourable evaluations of the royal family member. There was high internal consistency in responses using this scale for all members: Kate $(\alpha=.934$; $M=6.81 ; S D=1.03)$; Meghan $(\alpha=.922 ; M=5.44 ; S D=1.04)$; Diana $(\alpha=.90$; $M=2.34 ; S D=.856) ;$ William $(\alpha=.925 ; M=6.18 ; S D=1.09)$; Harry $(\alpha=.918$; $M=6.18 ; S D=1.09)$ and Charles $(\alpha=.916 ; M=5.38 ; S D=1.06)$.

Prior Knowledge Quiz. We created a Prior Knowledge Quiz to assess how much the participants already knew about the royal family. The scale consisted of 10 multiple choice questions of varying difficulty levels (see Appendix D). We coded each correct answer as 1 and incorrect answers as 0 , and then created a 
composite score by averaging all 10 questions. Scores on this scale $(M=.726$; $S D=.173)$ correlated with the participant's self-reported level of prior information $(\mathrm{r}=.300 ; \mathrm{p}<.001)$.

Media Exposure Scale. We included a measure to record how much media each participant consumed. The media sources (magazines, online news) were chosen carefully and only the ones that frequently publish news regarding the royal family were listed (see Appendix E). Participants rated how frequently they consumed news from each source. The responses ranged from 0 (never) to 4 (daily). A composite score was created by averaging the scores obtained for those 24 sources. This composite score, which we call the Media Exposure Scale $(M=.530, S D=.310)$ correlated positively with the Prior Knowledge quiz $(\mathrm{r}=.176 ; \mathrm{p}=.010)$ and self-reported prior information $(\mathrm{r}=.296 ; \mathrm{p}<.001)$.

Social Dominance Orientation. We used the six items from the SDO-6 scale (see Pratto et al., 1994). These included three items like, "It would be good if groups could be equal", and three reverse-scored items like, "Inferior groups should stay in their place" (see Appendix A). Participants could respond from 1 (strongly disagree) to 7 (strongly agree). Subsequently, we computed a composite score $(\alpha=.814 ; M=1.89 ; S D=.781)$.

Right-Wing Authoritarianism. RWA was assessed using six items the RWA scale (Altemeyer, 1998). These included items such as, "Our country will be destroyed someday if we do not smash the perversions eating away at our moral fibre and traditional beliefs". Again, half the items were reverse-coded and participants rated the extent to which they agreed with each item on a 7-point Likert scale, from 1 (strongly disagree) to 7 (strongly agree). These six items were averaged to create one variable for RWA $(\alpha=.670 ; M=3.05 ; S D=.915)$.

\section{Results}

Figure 1 shows the descriptive statistics for the composite score of each Royal member (the Royal Ratings scale) by experimental group. 
Figure 1

\section{Descriptive Statistics for Ratings of Royal Family Members}

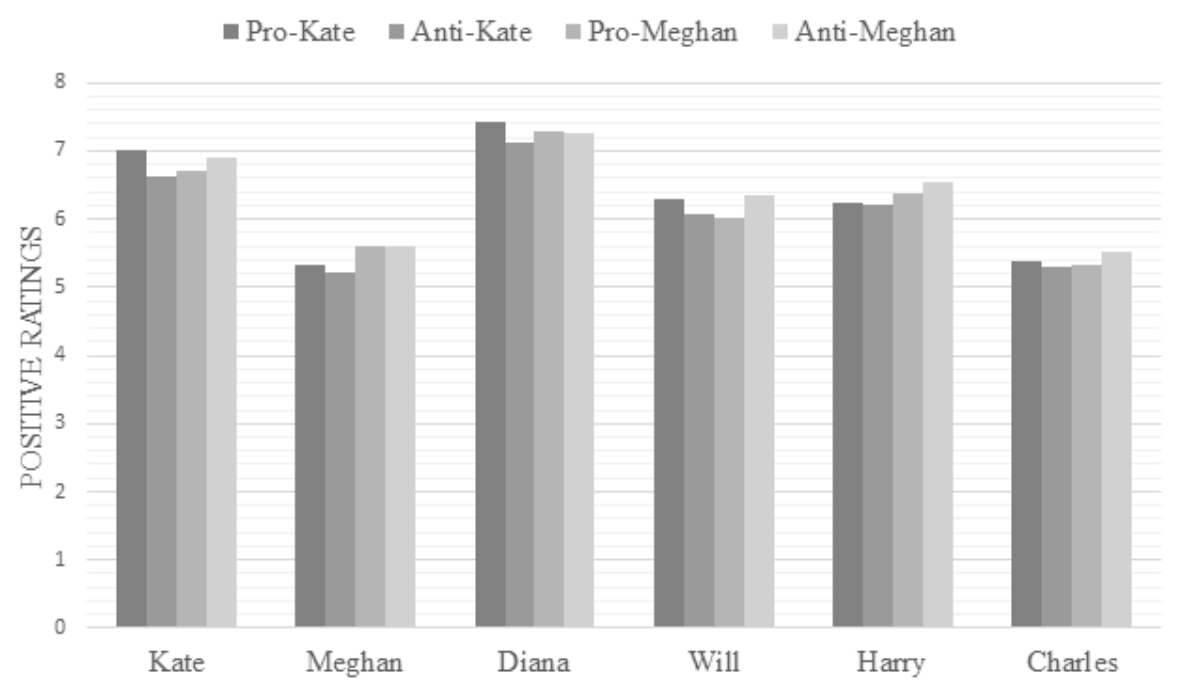

We used Pearson's correlations to understand how SDO, RWA and Prior Knowledge correlated with ratings for each royal member (see Table 1).

Table 1

Correlations Between Prior Information, SDO, RWA and Royal Ratings

\begin{tabular}{|c|c|c|c|c|c|c|c|c|c|}
\hline Variable & 1 & 2 & 3 & 4 & 5 & 6 & 7 & 8 & 9 \\
\hline 1. Pre-Knowledge & - & & & & & & & & \\
\hline 2. SDO & .034 & - & & & & & & & \\
\hline 3. RWA & -.019 & $.206^{* *}$ & - & & & & & & \\
\hline 4. Kate & $.222^{* *}$ & -.056 & -.042 & - & & & & & \\
\hline 5. Meghan & .064 & $-.152^{*}$ & -.074 & $.288^{* *}$ & - & & & & \\
\hline 6. Diana & $.146^{*}$ & -.107 & -.045 & $.485^{* *}$ & $.446^{* *}$ & - & & & \\
\hline 7. Will & $.280^{* *}$ & -.028 & .114 & $.576^{* *}$ & $.205^{* *}$ & $.319^{* *}$ & - & & \\
\hline 8. Harry & .093 & $-.146^{*}$ & -.071 & $.386^{* *}$ & $.652^{* *}$ & $.445^{* *}$ & $.290^{* *}$ & - & \\
\hline 9. Charles & -.029 & -.003 & $.141^{*}$ & $.214^{* *}$ & .075 & $.149 *$ & $.318^{* *}$ & .123 & - \\
\hline
\end{tabular}

Note. $* \mathrm{p}<.05, * * \mathrm{p}<.01$. 
The results of this analysis indicated that Prior Knowledge of the royal family correlated positively with ratings of Kate, William and Diana. On the other hand, SDO correlated negatively with ratings of Meghan and Harry (higher SDO = lower ratings). Finally, RWA correlated positively with ratings of Charles.

Next, we used a 4 (Caption Group: Pro-Kate, Anti-Kate, Pro-Meghan and Anti-Meghan) x 6 (Royal Ratings: one each for the six royal members) mixed model analysis of covariance (ANCOVA). Caption Group was a betweensubjects variable and Royal Ratings was a within-subjects variable. Based on the results of our preliminary correlation analysis, we entered SDO, RWA and Prior Knowledge as covariates in the model. The results of this analysis are presented below.

Table 2

Results of Mixed Model ANCOVA With Prior Knowledge, SDO and RWA as Covariates

\begin{tabular}{lrrl}
\hline \multicolumn{1}{c}{ Source } & \multicolumn{1}{l}{$p$} & $\eta_{p}{ }^{2}$ \\
& & & .023 \\
Royal Ratings & 6.86 & $<.001$ & .065 \\
Prior Knowledge & 20.51 & $<.001$ & .008 \\
SDO & 2.47 & .117 & .004 \\
RWA & 1.24 & .266 & .015 \\
Experimental Group & 1.50 & .214 & .021 \\
Royal Ratings x Prior Knowledge & 6.20 & $<.001$ & .004 \\
Royal Ratings x SDO & 1.04 & .388 & .016 \\
Royal Ratings x RWA & 4.72 & .001 & .011 \\
Royal Ratings x Experimental Group & 1.08 & .370 & \\
\hline
\end{tabular}

There was a main effect for Royal Ratings and Prior Knowledge and there were two significant interactions, first, between Royal Ratings and Prior Knowledge, and second, between Royal Ratings and RWA.

Figure 1 provides insight into the main effect for Royal Ratings, with Diana and Kate receiving the highest ratings, and Meghan and Charles the lowest. 
Therefore, we used multiple paired samples $t$-tests to understand how these scores differed, using Holms correction to ensure the family-wise error rate was maintained at $p<.05$. Evaluations were significantly higher for Kate than for Meghan: $t(215)=16.35, p<.001$; William: $t(215)=9.46, p<.001$; Harry: $t(215)=6.08, p<.001$; and Charles: $t(215)=16.03, p<.001$. Only Diana had significantly higher ratings than Kate, $t(215)=-6.93, p<.001$. Besides having lower ratings than Kate, Meghan also had significantly lower ratings than William: $t(215)=-8.13, p<.001$; Harry: $t(215)=-15.04, p<.001$; and Diana: $t(215)=-26.72, p<.001$. There were no other significant differences for Kate or Meghan.

Our correlation analysis had already indicated how Prior Knowledge, SDO and RWA varied for each Royal family member so there was no need for further exploration for any of these variables. Contrary to hypotheses, there were no effects for Experimental Group and that prior knowledge was a more important predictor.

\section{Discussion}

As discussed in the introduction, there has been a striking bias in the British tabloid press whereby Kate Middleton has been presented in a positive light in particular contexts, whereas Meghan Markle has been presented in a negative light in exactly the same contexts (Brookes, 2020; Mahfouz, 2018). It seems plausible that this consistent variation between the representations of these royal members may have impacted readers' perceptions. Nonetheless, no scientific study had examined how media framing has influenced attitudes toward these two royal family members. We examined the effect of picture caption framing in our experimental study by pairing pictures of Kate Middleton and Meghan Markle with either positive or negative text (taken from actual news stories). We found that picture caption manipulation had no effect on attitudes toward Kate Middleton or Meghan Markle, at least after a one-sitting exposure like in this experiment.

Arguably, in a real-life setting, a single exposure on social media is near impossible. Due to the algorithms, every search over successive days leads to several others pointing in the same direction (Druckman et al., 2012). This suggests that there is almost always repeated exposure to similar information. Although we tried to reinforce a particular viewpoint in our experiment by using six image-caption pairs all slanted consistently in either a positive or negative direction, our exposure was still limited to a single sitting within a few minutes. Future studies should look at how information reinforced repeatedly over successive days may impact media consumers' attitudes. 
Interestingly, our results indicated that general social attitudes - SDO and RWA - were also related to attitudes towards royal family members. SDO was negatively correlated with attitudes towards Meghan Markle and Prince Harry. While it is understandable that Meghan Markle could be seen as an outgroup member getting 'more than she deserves' by people high in SDO, it was interesting that the same pattern was observed for Prince Harry. There seem to be spill-over effects for Prince Harry due to his relationship with Meghan Markle or perhaps because he was the point of entry for Meghan Markle into the British royal family.

RWA positively correlated with evaluations for Prince Charles as people high in RWA have a strong regard for authority figures (Atemeyer, 1998) and, likewise, a strong support for monarchy as well. These results make sense given that RWA focuses on in-group submission whereas SDO emphasizes dominance over outgroup (Altemeyer, 1998; Sidanius \& Pratto, 1999). That is, RWA can be understood as a need for inter-group cohesion by submission to authority (Prince Charles) whereas SDO is a motive for out-group dominance. Plausibly, since Meghan Markle (and Prince Harry) violated the social hierarchy by allowing Meghan to join the Royal family, both Meghan and Harry were rated negatively by people high in SDO. It is possible that participants high in SDO were rating Meghan Markle based on her racial background or her strong leadership skills. In either case, they felt that Meghan was not deserving to be a part of the Royal family.

In sum, our study indicates that prior knowledge and ideological beliefs are stronger predictors of attitudes than positively or negatively framed captions, at least for political celebrities and in a one-time setting. It is noteworthy that long term exposure of biased media was so ingrained in the audience that a single exposure was not sufficient to cause any chance. This is reflected by the fact that Meghan Markle consistently received lower ratings across all four experimental groups. Therefore, it is likely that long term media exposure had already formed rigid opinions regarding her. It is also important to note that our respondents were all undergraduate students, and this could be a limitation in terms of the generalizability of the results across other groups in the society.

Future studies can look at how, if at all, repeated exposure over a period of time can sway audience into a predicted direction. Further studies could also explore how individuals high in SDO and RWA select what news to be exposed to. 


\section{References}

AMIR, Y. (1969). Contact hypothesis in ethnic relations. Psychological Bulletin, 7I(5), pp. 319-342. DOI: 10.1037/h0027352

ARDIFA, M. F., \& YAMIN, H. M. A. (2020). 'The construction of Meghan Markle's identity as a biracial woman in media reports', The International University Symposium on Humanities and Arts (INUSHARTS), Depok, Indonesia, 23 - 25 July, 20I9. DOI:10.2991/assehr.k.200729.029

ATEMEYER, B. (1998). The other "authoritarian personality". Advances in Experimental Social Psychology, 30, pp. 47-92. DOI: 10.1016/S0065-2601(08)60382-2

ATTIAH, K. (2018, May 18). No, Meghan Markle is not the 'modernizing' force Britain truly needs. The Washington Post. Available at: https://www.washingtonpost. com

ATWELL SEATE, A., \& MASTRO, D. (2016). Media's influence on immigration attitudes: An intergroup threat theory approach. Communication Monographs, 83(2), pp. 194-213. DOI: 10.1080/03637751.2015.1068433

BAKER, S. A. (2014). Social tragedy: The power of myth, ritual, and emotion in the new media ecology, New York, NY: Palgrave Macmillan.

BEHM-MORAWITZ, E., \& ORTIZ, M. (2013). Race, ethnicity, and the media. In: Dill, K. (Ed.), The Oxford handbook of media psychology, New York, NY: Oxford University Press. DOI: 10.1093/oxfordhb/9780195398809.013.0014

BROOKES, E. (2020). Side-by-side headlines make it starkly clear: The tabloids had it in for Meghan. Stuff. Available at: https://www.stuff.co.nz/life-style/ life/118811544/sidebyside-headlines-make-it-starkly-clear-the-tabloids-had-it-infor-meghan.

BROWN, W. J., BASIL, M. D., \& BOCARNEA, M. C. (2003). Social Influence of an International Celebrity: Responses to the Death of Princess Diana. Journal of Communication, 53(4), pp. 587-605. DOI: 10.1111/j.1460-2466.2003.tb02912.x

CHO, J., GIL DE ZUNIGA, H., SHAH, D. V., \& MCLEOD, D. M. (2006). Attitudes toward Target Minority Groups Measure. PsycTESTS Dataset. DOI:10.1037/t27392-000

CLANCY, L. (2019). "Queen"s Day - TV's Day': The British monarchy and the media industries. Contemporary British History, 33(3), pp. 427-450. DOI:10.1080/ 13619462.2019.1597710

COOLEY, E., BROWN-IANNUZZI, J. L., BROWN, C. S., \& POLIKOFF, J. (2017). Black groups accentuate hypodescent by activating threats to the racial hierarchy. Social Psychological and Personality Science, 9(4), pp. 411-418. DOI:10.1177/1948550617708014.

COULDRY, N. (2003) Media rituals: A critical approach, London, Routledge. 
CRANDALL, C. S., MILLER, J. M., \& WHITE, M. H. (2018). Changing Norms Following the 2016 U.S. Presidential Election. Social Psychological and Personality Science, 9(2), pp. 186- 192. DOI: 10.1177/1948550617750735

DAYAN, D., \& KATZ, E. (1992). Media events: The live broadcasting of history. Cambridge, MA: Harvard University Press. https://doi.org/10.1080/00224545.1 993.9712181

DIXON, T. L., \& LINZ, D. (2000). Overrepresentation and Underrepresentation of African Americans and Latinos as Lawbreakers on Television News. Journal of Communication, 50(2), pp. 131-154. DOI: 10.1111/j.1460-2466.2000.tb02845.x

DRAGOJEVIC, M., SINK, A., \& MASTRO, D. (2016). Evidence of Linguistic Intergroup Bias in U.S. Print News Coverage of Immigration. Journal of Language and Social Psychology, 36(4), pp. 462-472. DOI: 10.1177/0261927x16666884

DUCKITT, J. (1993). Right-wing authoritarianism among white South African students: Its measurement and correlates. Journal of Social Psychology, 133, pp. 553-563.

DUNAWAY, J., BRANTON, R., \& ABRAJANO, M. (2007). Agenda Setting, Public Opinion, and the Issue of Immigration Reform. SSRN Electronic Journal. DOI: $10.2139 /$ ssrn. 1017846

EBERHARDT, J. L. (2019). Biased: Uncovering the Hidden Prejudice That Shapes What We See, Think, and Do, New York, Viking.

ENTMAN, R. M. (1991). Framing U.S. coverage of international news: Contrasts in narratives of the KAL and Iran air incidents. Journal of Communication, 41, pp. 6-27.

ENTMAN, R. M. (1993). Framing: Towards clarification of a fractured paradigm. Journal of Communication, 43, pp. 51-58.

ERIKSSON, F. (2020). Constructing a Princess: Evaluation of Meghan Markle and Kate Middleton in a British Tabloid [Independent thesis Basic level (degree of Bachelor)]. Stockholm University, Faculty of Humanities. Available at: http://urn. kb.se/resolve?urn = urn:nbn:se:su:diva-182491

FRAMPTON, B. (2015). Is clickbait changing journalism? BBC. Available at: https://www.bbc.com/news/uk-wales-34213693 (Accessed: 30 August 2020)

FREDERICK, D. A., TOMIYAMA, A. J., BOLD, J. G., \& SAGUY, A. C. (2020). Can she be healthy at her weight? Effects of news media frames on antifat attitudes, dieting intentions, and perceived health risks of obesity. Stigma and Health, 5(3), pp. 247-257. DOI: 10.1037/sah0000195

FÜRST, S. (2020) "The Whole World Watching"? How News Media Create the Myth of an Audience of Billions and Foster Imagined Communities. International Journal of Communication I4, pp. 1524-1541. 
GOFFMAN, E. (1974). Frame analysis: An essay on the organization of experience, New York, NY et al.: Harper \& Row. Available at: https://is.muni.cz/el

GOSLING, S. D., RENTFROW, P. J., \& SWANN, W. B. (2003). A very brief measure of the Big-Five personality domains. Journal of Research in Personality, 37(6), pp. 504-528. DOI: 10.1016/s0092-6566(03)00046-1

GRUNIG, J. E. 1993. Image and substance: From symbolic to behavioral relationships. Public Relations Review, 19(2), pp. 121-139.

GWARJANSKI, A. R., \& PARROTT, S. (2017). Schizophrenia in the news: The role of news frames in shaping online reader dialogue about mental illness. Health Communication, 33(8), pp. 954-961. DOI: 10.1080/10410236.2017.1323320

HANSON-EASEY, S. \& AUGOUSTINOS, M. (2010) Out of Africa: Accounting for refugee policy and the language of causal attribution. Discourse \& Society 21(3), pp. 295-323. DOI: 10.1177/0957926509360744

HUBER, G. A., LAPINSKI, J. S. (2006). The "race card" revisited: Assessing racial priming in policy contests. American Journal of Political Science, 50, pp. 421-440. DOI: 10.1111/j.1540-5907.2006.00192.x

HUNTER, J., STRINGER, M., BANKS, M., KAFKA, S., IVERSEN, G., SCOBIE, O., HU, Q., HAYHURST, J. (2015). Collective Identity and Intergroup Discrimination: Outcomes in Contexts that Emphasize and do not Emphasize Intergroup Relations. International Journal of Psychology \& Behaviour Analysis, 1(1). DOI: 10.15344/24553867/2015/105

JACOBS, L., \& VAN DER LINDEN, M. (2017). Tone Matters: Effects of Exposure to Positive andNegative Tone of Television News Stories on Anti-Immigrant Attitudes and Carry- Over Effects to Uninvolved Immigrant Groups. International Journal of Public Opinion Research, 30(2), pp. 211-232. DOI: 10.1093/ijpor/edw036

JOHNSON, M., STEIN, R. M., \& WRINKLE, R. (2003). Language Choice, Residential Stability, and Voting Among Latino Americans. Social Science Quarterly, 84(2), 412-424. DOI:10.1111/1540-6237.8402012

LEVY, M. R. (1979). Watching TV news as para-social interaction. Journal of Broadcasting, 23(1), pp. 69-80. DOI:10.1080/08838157909363919

LINENTHAL, E. T. (2001) The unfinished bombing: Oklahoma City in American memory, New York: Oxford University Press.

Lukes, S. (1975). Political ritual and social integration. Sociology, 29, pp. 289305.

Mahfouz, I. M. (2018). The Representation of Meghan Markle in Facebook Posts: A discourse historical approach (DHA). International Journal of Language \& Linguistics, 5(3). DOI:10.30845/ijll.v5n3p24 
MASTRO, D., \& TUKACHINSKY, R. (2011). The influence of exemplar versus prototype-based media primes on racial/ethnic evaluations, Journal of Communication, 61 (5), pp. 916-937. DOI: 10.1111/j.1460-2466.2011.01587.x

MCCOMBS, M., \& SHAW, D. (1972). The agenda-setting function of mass media. The Public Opinion Quarterly, 36(2), pp. 176-187. Available at: http://www.jstor.org

MCNAMARA, K. (2011). The paparazzi industry and new media: The evolving production and consumption of celebrity news and gossip websites. International Journal of Cultural Studies, 14(5), pp. 515-530. DOI: 10.1177/1367877910394567

MYERS, G. (2000). Entitlement and sincerity in broadcast interviews about Princess Diana. Media, Culture \& Society, 22(2), pp. 167-185.

OLIVER, W. (1994). The violent social world of black men, New York, Lexington.

PAYNE, J. G. (2000). Preface to an era of celebrity and spectacle. In: G. Payne (Ed.), An era of celebrity and spectacle: The global rhetorical phenomenon of the death of Diana, Princess of Wales, Boston, Center for Ethics in Political and Health Communication, Emerson College.

PRATTO, F., SIDANIUS, J., STALLWORTH, L. M., \& MALLE, B. F. (1994). Social dominance orientation: A personality variable predicting social and political attitudes. Journal of Personality and Social Psychology, 67(4), pp. 741-763. DOI: 10.1037/0022-3514.67.4.741

PUIJK, R. (2009). Intense media coverage. Communications, 34(1), pp. 1-20.

RAMASUBRAMANIAN, S., DOSHI, M. \& SALEEM, M. (2017). Mainstream versus ethnic media: How they shape self-esteem and ethnic pride among ethnic minorities. International Journal of Communication, 11(1-21), pp. 1879-1899. Available at: https://ijoc.org

RIBOT, A. F. (2019). A linguistic analysis of the representation of Kate Middleton and Meghan Markle in the British press: A corpus-based study. Available at: https:// dspace.uib.es/

SIDANIUS, J., \& PRATTO, F. (1999). Social dominance: An intergroup theory of social hierarchy and oppression, New York, Cambridge University Press.

STAPLES, R. (2011). White Power, Black Crime, and Racial Politics. The Black Scholar, 41(4), pp. 31-41. DOI: 10.1080/00064246.2011.11413574

THOMAS, J. (2008). From people power to mass hysteria: Media and popular reactions to the death of Princess Diana. International Journal of Cultural Studies, 11(3), pp. 362-376.

TUKACHINSKY, R., MASTRO, D., \& YARCHI, M. (2015). Documenting portrayals of race/ethnicity on primetime television over a 20-year span and their association with national-level racial/ethnic attitudes. Journal of Social Issues, 71(1), pp. 1738. DOI: $10.1111 /$ josi.12094 
TVERSKY, A., \& KAHNEMAN, D. (1981). The framing of decisions and the psychology of choice. Science, 211, pp. 453-458.

VAN DIJK, T. A. (2006). Discourse and manipulation. Discourse \& Society, 17, pp. 359-383.

WEAVER, D. H. (2007). Thoughts on Agenda Setting, Framing, and Priming. Journal of Communication, 57(1), pp. 142-147. DOI: 10.1111/j.14602466.2006.00333.x

Why can't Meghan Markle keep her hands off her bump? Experts tackle the question. (2019). Available at: https://www.dailymail.co.uk/news/article-6636233/WhyMeghan-Markle-hands-bump-Experts-tackle-question.html (Accessed: August 24, 2020)

WILSON, M. S., \& SIBLEY, C. G. (2012). Social Dominance Orientation and RightWing Authoritarianism: Additive and Interactive Effects on Political Conservatism. Political Psychology, 34(2), pp. 277-284. DOI: 10.1111/j.1467-9221.2012.00929.x 


\section{Appendix A SDO and RWA}

Instruction: Show how much you favour or oppose each idea below by selecting a number from 1-7 on the scale below. You can work quickly, your first feeling is generally best.

$\begin{array}{llllccc}1 & 2 & 3 & 4 & 5 & 6 & 7 \\ \text { Strongly } & \text { Somewhat } & \text { Slightly } & \text { Neutral } & \text { Slightly } & \text { Somewhat } & \text { Strongly } \\ \text { Oppose } & \text { Oppose } & \text { Oppose } & & \text { Favor } & \text { Favor } & \text { Favor }\end{array}$

\section{SDO Short version}

1. It is OK if some groups have more of a chance in life than others.

2. Inferior groups should stay in their place.

3. To get ahead in life, it is sometimes okay to step on other groups.

4. We should have increased social equality.

5. It would be good if all groups could be equal.

6. We should do what we can to equalize conditions for different groups.*

\section{RWA Short version}

1. It is always better to trust the judgment of the proper authorities in government and religion than to listen to the noisy rabble-rousers in our society who are trying to create doubt in people's minds.

2. It would be best for everyone if the proper authorities censored magazines so that people could not get their hands on trashy and disgusting material.

3. Our country will be destroyed someday if we do not smash the perversions eating away at our moral fibre and traditional beliefs.

4. People should pay less attention to The Bible and other old traditional forms of religious guidance, and instead develop their own personal standards of what is moral and immoral.*

5. Atheists and others who have rebelled against established religions are no doubt every bit as good and virtuous as those who attend church regularly.*

6. Some of the best people in our country are those who are challenging our government, criticizing religion, and ignoring the «normal way» things are supposed to be done.*

*Reversed 


\section{Appendix B Experimental Conditions}

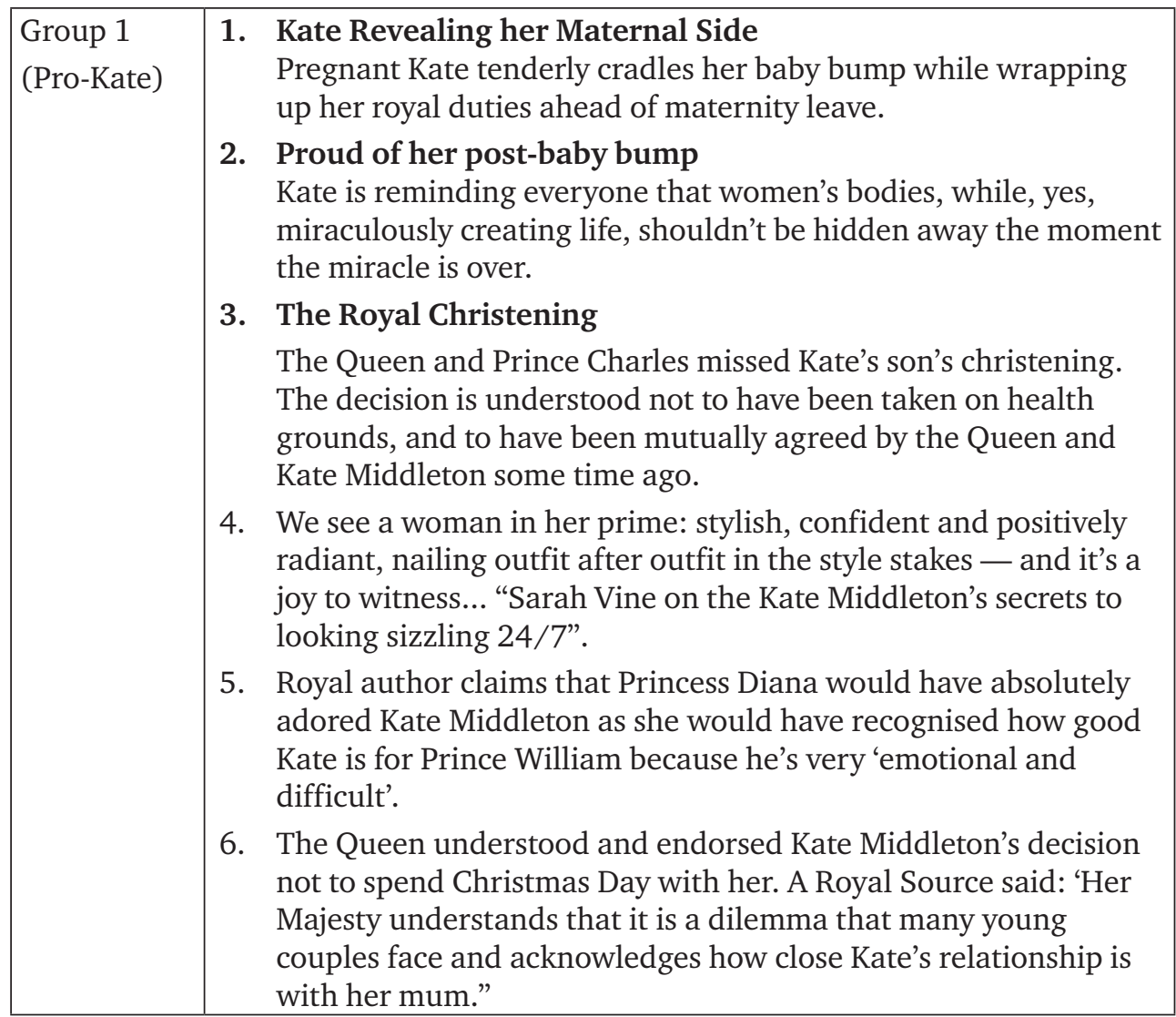




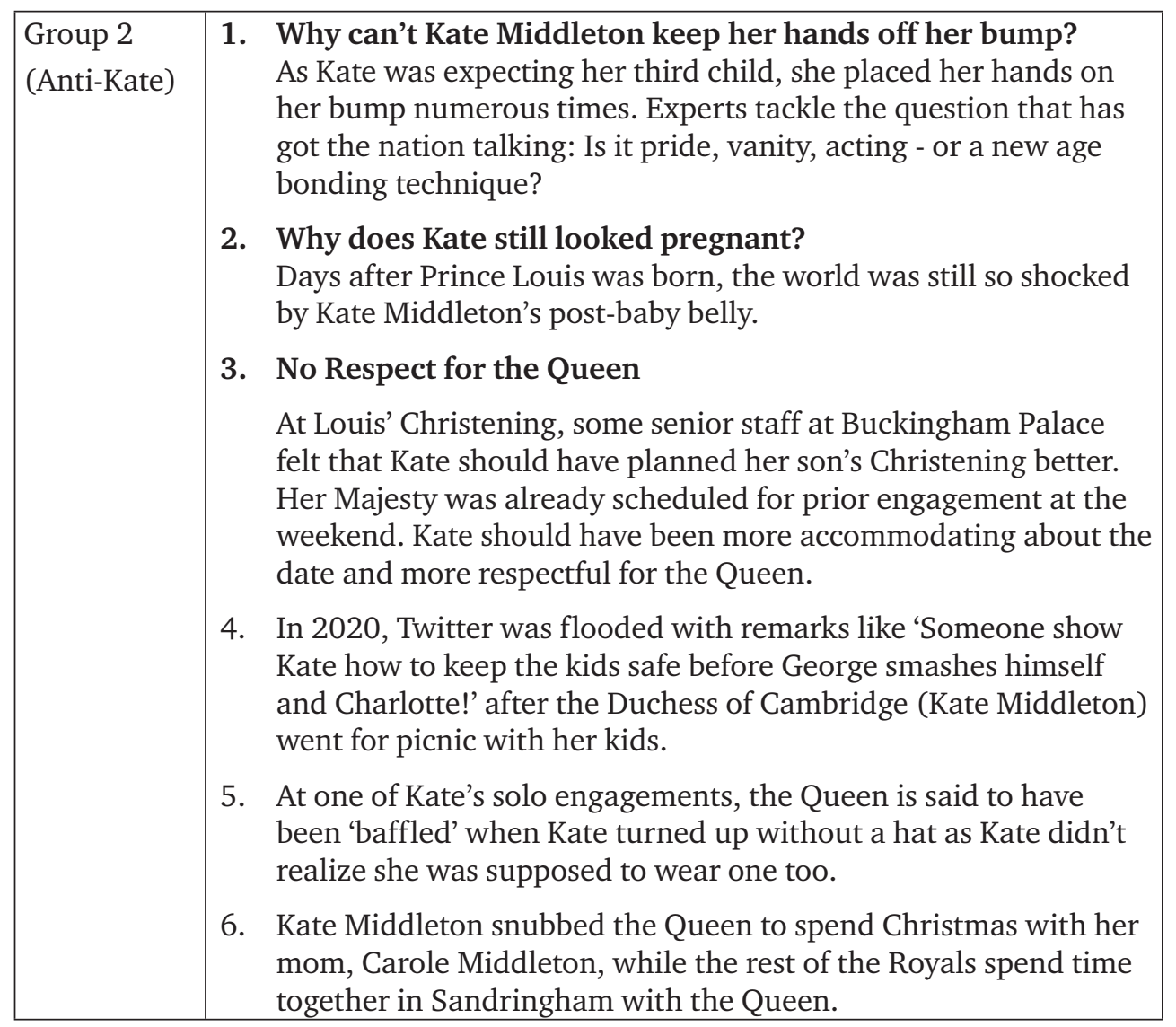




\begin{tabular}{|c|c|}
\hline $\begin{array}{l}\text { Group } 3 \\
\text { (Pro-Meghan) }\end{array}$ & $\begin{array}{l}\text { 1. Meghan Revealing her Maternal Side } \\
\text { Pregnant Meghan tenderly cradles her baby bump while } \\
\text { wrapping up her royal duties ahead of maternity leave. } \\
\text { 2. Proud of her post-baby bump } \\
\text { Meghan is reminding everyone that women's bodies, while, yes, } \\
\text { miraculously creating life, shouldn't be hidden away the moment } \\
\text { the miracle is over. } \\
\text { 3. The Royal Christening } \\
\text { The Queen and Prince Charles missed Meghan's son's } \\
\text { christening. The decision is understood not to have been taken } \\
\text { on health grounds, and to have been mutually agreed by the } \\
\text { Queen and Meghan Markle some time ago. } \\
\text { 4. We see a woman in her prime: stylish, confident and positively } \\
\text { radiant, nailing outfit after outfit in the style stakes - and it's a } \\
\text { joy to witness... "Sarah Vine on the Meghan Markle's secrets to } \\
\text { looking sizzling 24/7. } \\
\text { 5. Royal author claims that Princess Diana would have absolutely } \\
\text { adored Meghan Markle as she would have recognised how good } \\
\text { Meghan is for Prince Harry because he's very 'emotional and } \\
\text { difficult'. } \\
\text { The Queen understood and endorsed Meghan Markle's decision } \\
\text { not to spend Christmas Day with her. A Royal Source said: 'Her } \\
\text { Majesty understands that it is a dilemma that many young } \\
\text { couples face and acknowledges how close Meghan's relationship } \\
\text { is with her mum." }\end{array}$ \\
\hline
\end{tabular}




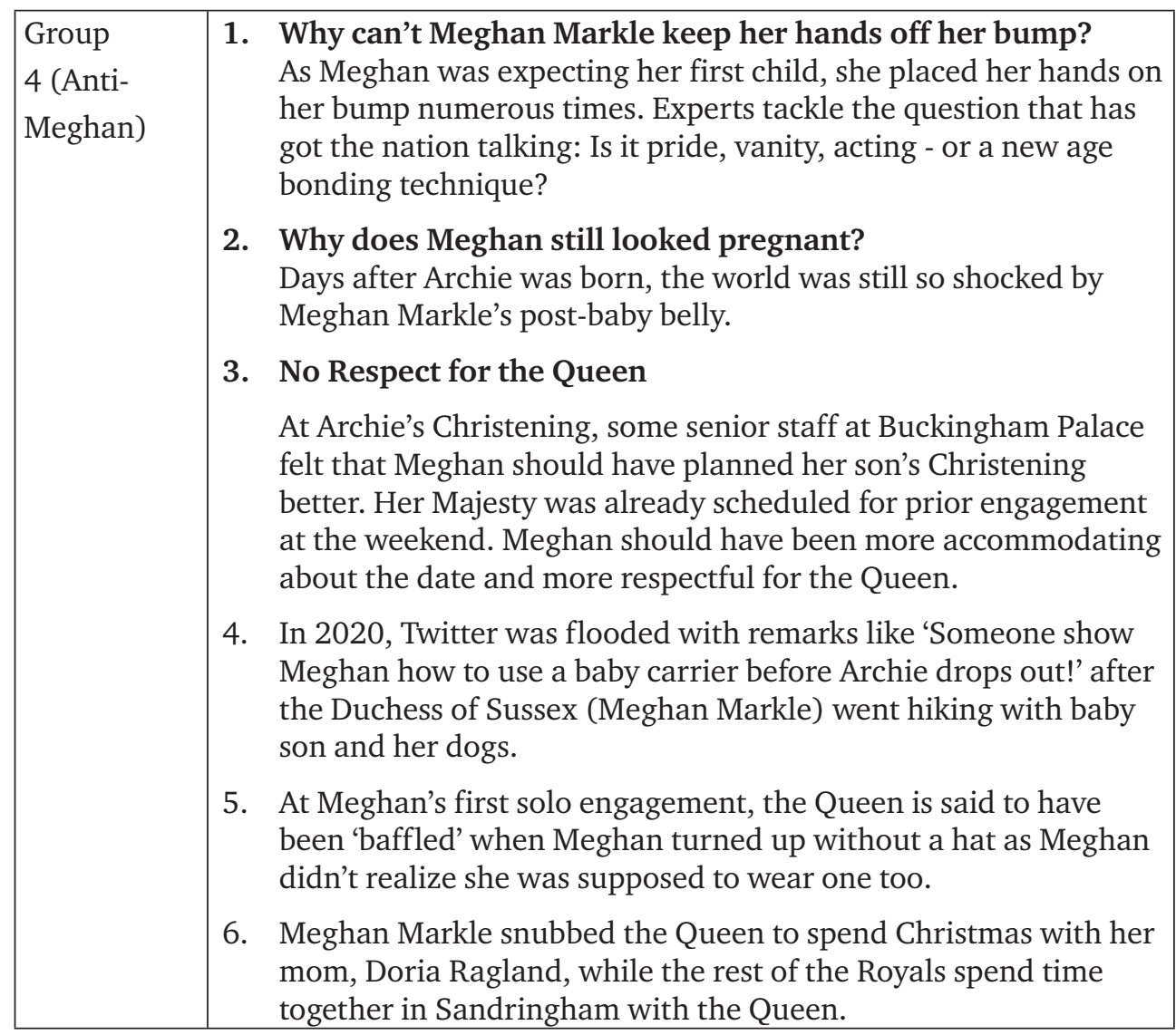




\section{Appendix C Royal Family Evaluation}

On the whole, how would you rate Kate Middleton, Duchess of Cambridge on the following dimensions?

$$
\begin{array}{lllllllll}
1 & 2 & 3 & 4 & 5 & 6 & 7 & 8 & 9
\end{array}
$$

Competitive

$\bigcirc \bigcirc \bigcirc \bigcirc \bigcirc \bigcirc \bigcirc \bigcirc \bigcirc$ Co-operative

Helpful

$\bigcirc \bigcirc \bigcirc \bigcirc \bigcirc \bigcirc \bigcirc \bigcirc \bigcirc$ Unhelpful*

Unintelligent

$\bigcirc \diamond \diamond \diamond \diamond \bigcirc \bigcirc \bigcirc \bigcirc$ Intelligent

Weak

$\circ \circ \bigcirc \bigcirc \circ \bigcirc \bigcirc \circ \bigcirc$ Strong

Warm

$0 \bigcirc 0 \bigcirc 0 \bigcirc \bigcirc \circ \circ$

Rigid

Unselfish

000000000

Cold*

Flexible

Manipulative

$\circ \circ \bigcirc \circ \bigcirc \circ \bigcirc \bigcirc \circ$

$\circ \circ \bigcirc \circ \bigcirc \circ \circ \bigcirc \circ$

Selfish*

Fair

$\circ \bigcirc \bigcirc \bigcirc \circ \bigcirc \bigcirc \bigcirc \bigcirc$ Sincere

Honest

$\bigcirc \bigcirc \bigcirc \bigcirc \bigcirc \bigcirc \bigcirc \bigcirc \bigcirc$ Unfair*

Unfriendly

$\bigcirc \bigcirc \bigcirc \bigcirc \bigcirc \bigcirc \bigcirc \bigcirc \bigcirc$ Dishonest*

Trustworthy

$\circ \bigcirc \bigcirc \diamond \bigcirc \bigcirc \bigcirc \bigcirc \diamond$ Friendly

Consistent

$\bigcirc \bigcirc \bigcirc \bigcirc \bigcirc \bigcirc \bigcirc \bigcirc \bigcirc$ Untrustworthy*

Loud

000000000

Inconsistent*

Pushy

$\bigcirc \bigcirc \bigcirc \bigcirc \bigcirc \bigcirc \bigcirc \bigcirc \bigcirc$ Soft-spoken

Humble

$\circ \bigcirc \bigcirc \bigcirc \bigcirc \bigcirc \bigcirc \bigcirc \circ$

Reticent

Confident

000000000

Arrogant*

Aggressive

$\bigcirc \bigcirc \bigcirc \bigcirc \bigcirc \bigcirc \bigcirc \bigcirc \bigcirc$ Shy*

Ignorant

$\bigcirc \bigcirc \bigcirc \bigcirc \bigcirc \bigcirc \bigcirc \bigcirc \bigcirc$ Non-aggressive

$\bigcirc \bigcirc \bigcirc \bigcirc \bigcirc \bigcirc \bigcirc \bigcirc \bigcirc$ Well informed

$\bigcirc \bigcirc \bigcirc \bigcirc \bigcirc \bigcirc \bigcirc \bigcirc \bigcirc$ Straightforward Hypocritical*

*Reversed

The same scale was repeated to obtain ratings for Princess Diana, Meghan Markle, Prince William, Prince Harry and Prince Charles as well. 


\section{Appendix D Prior Knowledge Quiz}

Britain is one of a number of countries today that is a monarchy - in other words, the head of state isn't elected like the Presidents of the United States or France, but inherits the job from their parents. It sounds like an old-fashioned system, and it is - kings and queens have ruled in Britain for around 1600 years. This study is about the Royal Family. You will be required to examine some reading material with images and later answer questions related to it. But first, let's see how well you know the Royal Family already...

1. What is the name of the current queen?

a Mary III

Elizabeth II

Georgiana

a Anna

2. Who is married to Queen Elizabeth II?

口 Prince Phillip, Duke of Edinburgh

P Prince Henry of Wales

Prince Edward, Duke of Kent

r Prince William, Duke of Cam

3. The famous Princess Diana was the princess of:

a Cornwall

Cambridge

a Wales

Y York

4. What is the official title for Prince Harry?

ㅁ Duke of Wales

口 Duke of Edinburgh

口 Duke of Sussex

- Duke of Cambridge

5. Which Royal Baby was born in April 2018?

a Prince Harry

a Prince Louis

․ Prince George

a Prince Andrew 
6. How many children do William and Kate have?

Four

Twins

․ Three

$\square$ One

7. What colour clothes to the royals always have on hand?

B Brown

$\square$ Red

口 Navy

B Black

8. What food are the royals generally forbidden from eating?

$\square$ Chicken.

- Shellfish.

口 Pasta.

ㅁ Goose.

9. Who is next in line for the throne?

口 Prince Charles

口 Princess Charlotte

口 Prince Edward

口 Prince Harry

10. What is the royal family's nickname for Kate?

- They simply call her Kate.

- They call her Catherine, as nicknames are not permitted.

口 Katie!

口 Katy-did! 


\section{Appendix E Media Exposure}

$\begin{array}{lcccc}1 & 2 & 3 & 4 & 5 \\ \text { Never } & \text { Once a year } & \text { Once a month } & \text { Once a week } & \text { Daily }\end{array}$

How frequently do you read these newspapers/magazines? Just enter the number of hours on average.

Daily Mail

The Sun

Daily Express

Daily Mirror

The People

Metro

Morning Star

Daily Star

The Times

The Telegraph

The Observer

The Independent

The Daily Record

The Guardian

BBC News

The Australian Women's Weekly (NZ)

That's Life

New Zealand Woman's Weekly.

Woman's Day 